\title{
Bioresorbable Plates and Screws for Clinical Applications: A Review
}

\author{
Sandra Pina* and José M.F. Ferreira \\ University of Aveiro, Deptartment of Ceramics and Glass Engineering, Centro de \\ Investigação de Materiais Cerâmicos e Compósitos, 3810-193 Aveiro, Portugal
}

Submitted January 2011. Accepted for publication November 2011.

\begin{abstract}
Bioresorbable implants are being widely used for fracture fixation in orthopaedic surgery and the market is expanding rapidly worldwide. Bioresorbable materials slowly dissolve in the human body, such that a second operation to remove the synthetic material is not needed. Bioresorbable implants have expanded the armamentarium of the surgeon, especially in the field of sports medicine. Interference screws, plates, pins, suture anchors, meniscal repair implants, and simple fracture fixation implants are the most commonly used resorbable implants for anterior cruciate ligament reconstruction, shoulder surgery, meniscal repair, and fracture care. However, many clinicians continue to rely on metal fixation, mainly due to the high mechanical strength and to the complications reported with some of the available resorbable implant materials. The goal of the present paper is to present an overview on the available resorbable materials and their applications with a particular focus on new developments and trends in the field.
\end{abstract}

Keywords: bioresorbable, internal fixation, plates and screws, calcium phosphates, polymers

\section{INTRODUCTION}

A key goal of orthopaedic medicine is to restore the structure of damaged or diseased bone tissue to a natural state. Internal fixation implants that are stronger, more acceptable to the body, cheaper and durable have been developed to improve bone fracture osteosynthesis, to attach soft tissues or tissue grafts to bone for more than two decades. Such implants comprise screws, plates, pins, staples and suture anchors which are commonly fabricated of metals such as stainless steel and titanium and its alloys. However, there are intrinsic problems with the use of these metallic implants, such as stress-shielding phenomenon, pain, and local irritation [1-3].

\footnotetext{
*Corresponding author: Sandra Pina, University of Aveiro, Dept. of Ceramics and Glass Engineering, CICECO, 3810-193 Aveiro, Portugal. Phone: (+351) 234370 200. Fax: (+351) 234370985. E-mail: sandra.pina@ua.pt. Other author: jmf@ua.pt.
} 
Retained metallic implants are always at the risk of endogenous infection [4]. In addition, metal plate-screws might lead to destruction and osteoporosis in the surrounding bone tissue [5]. For these reasons, there is need for a second surgery to remove the metallic fixation after the bone has healed [2].

Bioresorbable and biodegradable fracture fixation implants have been considered as an effective fixation system with several advantages over metallic fixation, including no need to remove the implants after osseous healing, radiolucency, no corrosion, no accumulation of metal in tissues, less pain and reduced stress-shielding since the implants bear less load initially and gradually transfer the load as they degrade [6-12]. These devices are most often manufactured from polylactides (polylactic acid, PLA), polyglycolides (polyglycolic acid, PGA) and their co-polymer compositions as they are highly resorbable [13-14]. Commercially available resorbable implants are summarized in Table 1.

Bioresorbable materials allow a newly formed tissue to grow into any surface irregularities [15-17]. Thus, a resorbable implant is free of toxic and mutagenic effects. Nonetheless, there are some problems related to the use of these implants, such as an inflammatory response, rapid loss of initial implant strength, higher refracture rates, inadequate stiffness of the implants, and weakness in comparison to metallic implants $[1,18]$. Table 2 summarizes some of the problems observed with the implementations of common bioresorbable materials.

Biodegradable implants are characterized by materials that show disintegration after implantation but with no proof of its elimination from the body [19]. The biodegradation process depends on contact with body fluids, temperature, motion, molecular weight, crystal form and geometry of material, and the tissue that is implanted [20-21]. The ideal biodegradable material provides appropriate strength whilst degrading in a predictable fashion throughout the healing process without causing adverse reactions [22].

The first study on the use of biodegradable implants was published in 1966 by Kulkarni et al. [23], who studied the biocompatibility of poly-L-lactic (PLLA) in animals. The material proved to be non-toxic and gradually degraded. The use of PLLA plates and screws to fix mandibular fractures in dogs was studied by Kulkarni et al. [24]. Another study presented the results of PLLA sutures in mandibular fractures with no serious tissue reactions [25].

A common use of biodegradable interference screws is for the anterior cruciate ligament reconstruction. A recent study showed the potential of these screws as an alternative to titanium screws for the fixation of autologous bone grafts in dental implants [26].

The limitations of biodegradable implants are mainly in their mechanical properties which are lower than those of conventional metal implants, leading to low confidence levels regarding the stability of reduced fractures. Also, the construction of screws and pins for the necessary compression between the implant and the bone is somehow difficult [27-28]. The biocompatibility is another limitation of these materials since they sometimes provoke an adverse tissue response that has the characteristic of an inflammatory, bacterial foreign-body reaction [29-34]. 


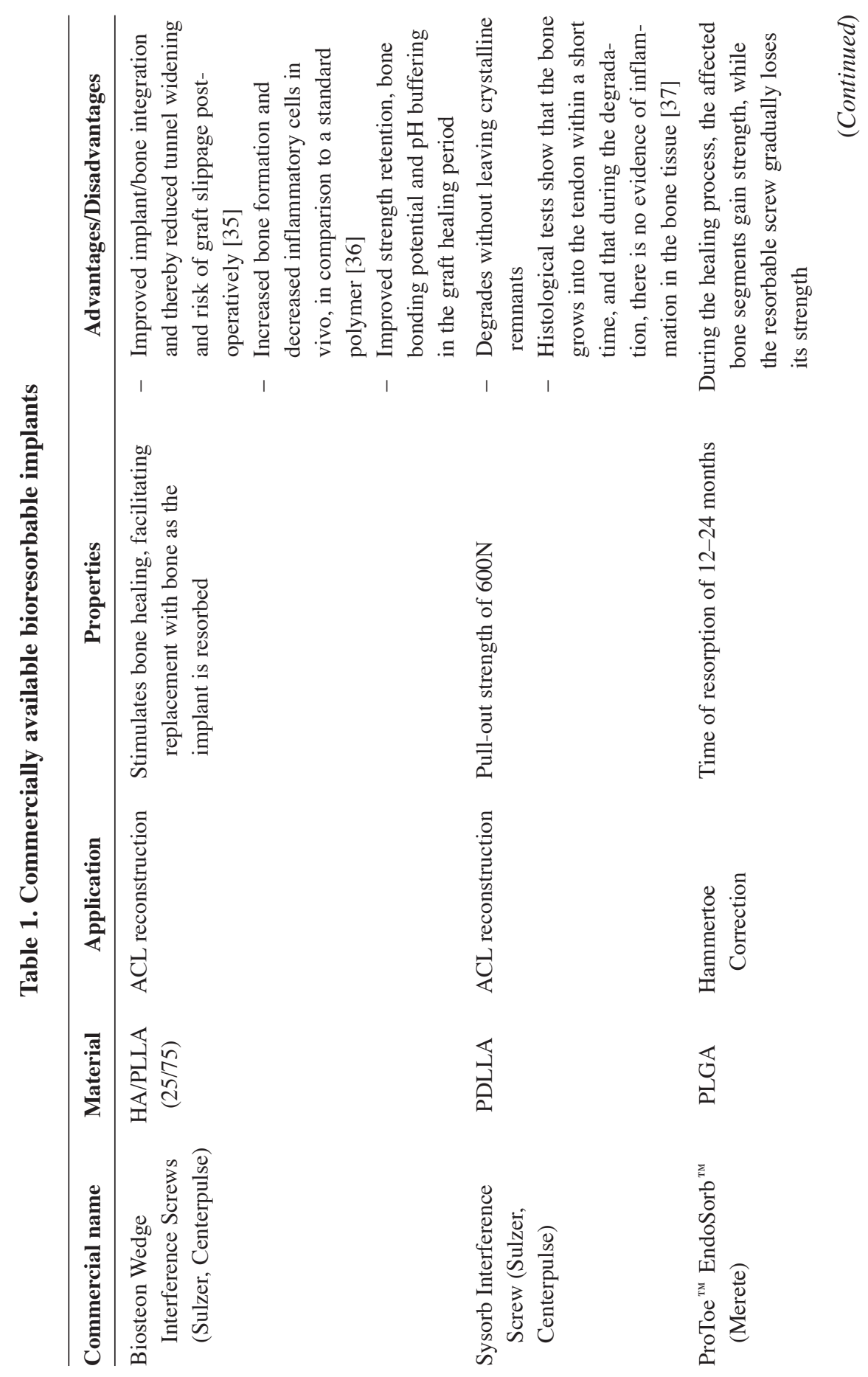




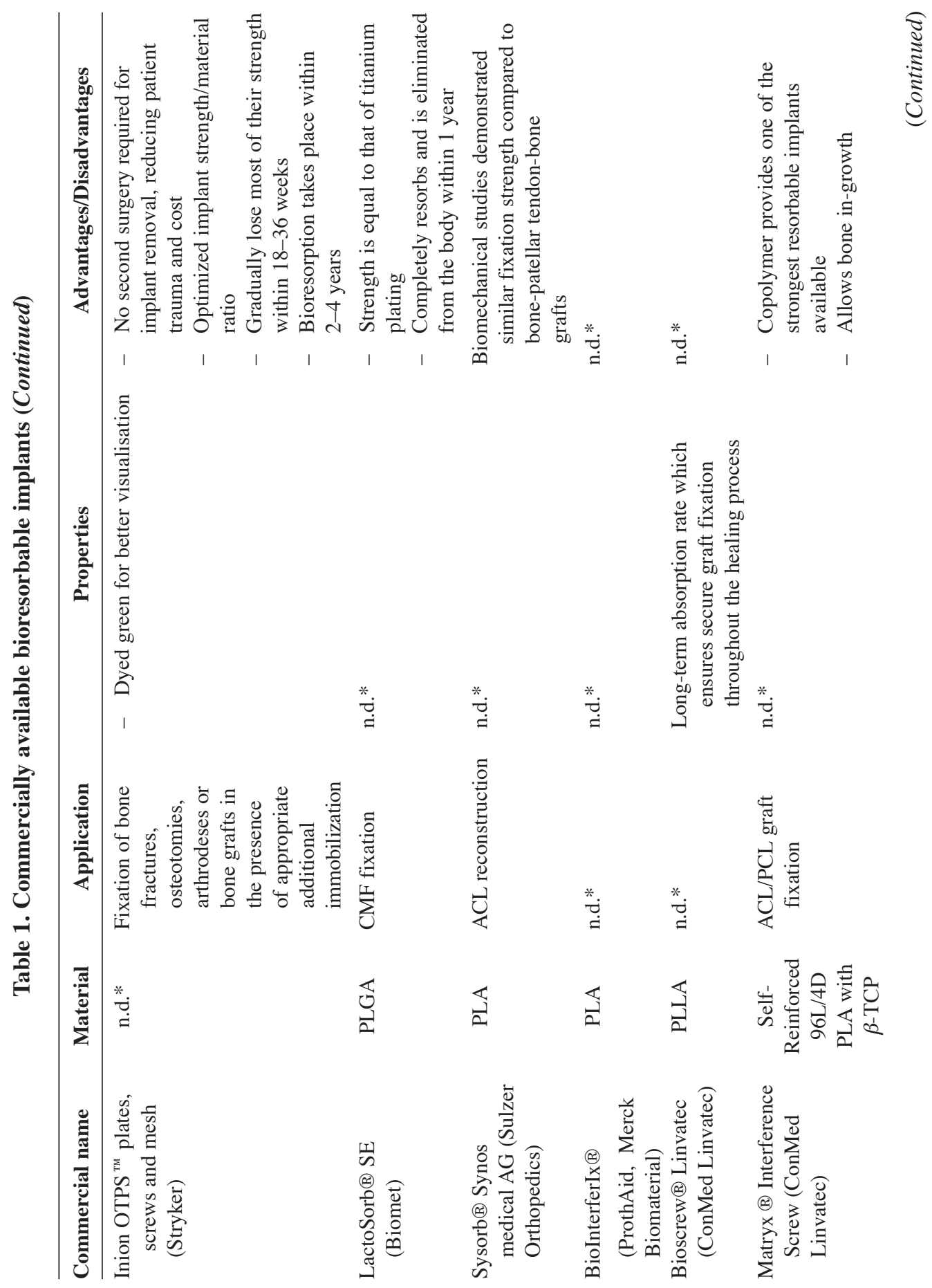




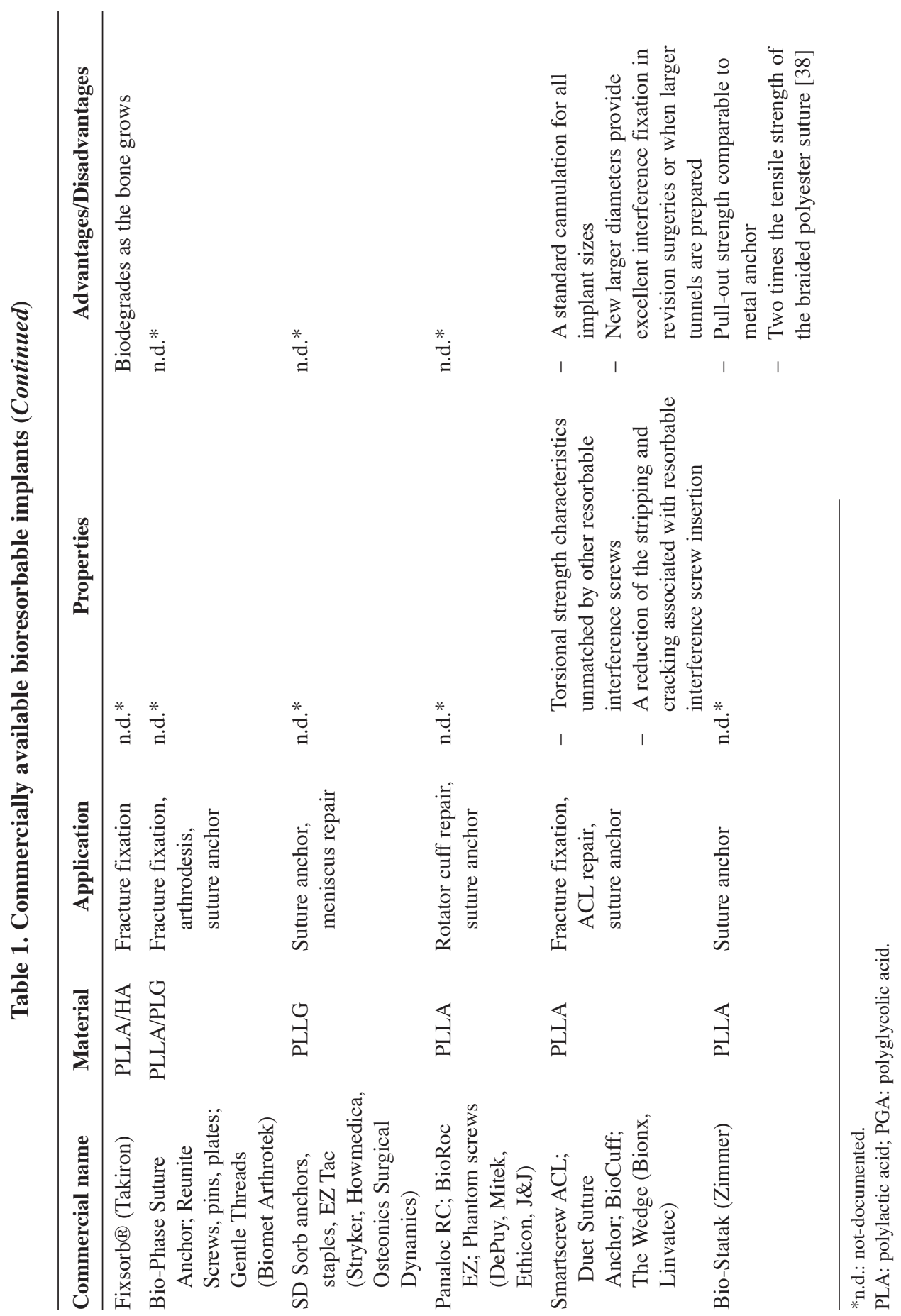


Table 2. Summary of complications associated with bioresorbable implants

\begin{tabular}{|c|c|c|c|c|c|c|}
\hline $\begin{array}{l}\text { Patients } \\
(\%)\end{array}$ & Follow-up & Material & $\begin{array}{l}\text { Implant } \\
\text { type }\end{array}$ & $\begin{array}{l}\text { Implant } \\
\text { site }\end{array}$ & $\begin{array}{c}\text { Results/ } \\
\text { complications }\end{array}$ & Ref. \\
\hline 1.3 & n.d.* & PGA & Pin & Toe & Fluid & [39] \\
\hline 49 & $2-4 \mathrm{mths}$ & PGA & Pin & Ankle & $\begin{array}{l}\text { Discharge/ } \\
\text { Osteolysis }\end{array}$ & {$[40]$} \\
\hline 6.3 & $2-4$ mths & PGA & Pin & Ankle & Swelling & [33] \\
\hline 11 & $5-26$ wks & PGA & Screw & Ankle & Swelling & [32] \\
\hline 0 & 10-44 mths & PGA & Pin & Elbow & none & [41] \\
\hline 5 & n.d.* & PGA & Screw & Shoulder & Sinus & [42] \\
\hline 6.8 & n.d.* & PGA & Pin & Ankle/Elbow & Discharge & [43] \\
\hline 6.5 & n.d.* & $\begin{array}{l}\text { PGA/PLA, } \\
\text { PGA }\end{array}$ & Pin & Canc. bone & Fluid & {$[44]$} \\
\hline 4 & $2 \mathrm{mths}$ & PGA & Pin & $\begin{array}{l}\text { Osteo-chondral } \\
\text { fractures }\end{array}$ & Swelling & {$[45]$} \\
\hline 7.9 & $2-4$ mths & PGA & Pin & Multiple & Swelling & [32] \\
\hline 0 & $21-59 \mathrm{mths}$ & PLA & Screw & Ankle & none & [46] \\
\hline 100 & $3.3-5.7 \mathrm{yrs}$ & PLLA & Plates/screws & Zygoma & Swelling & [47] \\
\hline 0 & $3.5-6.6 \mathrm{yrs}$ & PLLA & Discs & Orbital floor & none & [48] \\
\hline 0 & $8-37$ mths & PLLA & Pin & Multiple & none & [49] \\
\hline 0 & $6 \mathrm{mths}$ & PLLA & Mini tack & Wrist & none & {$[50]$} \\
\hline 16 & $3.5-18 \mathrm{mths}$ & PLLA & Suture anchor & Bankart & $\begin{array}{c}\text { Osteolysis and } \\
\text { arthropathy }\end{array}$ & {$[51]$} \\
\hline 47 & n.d.* & PLLA & Suture anchor & Stabilization & Asymptomatic & {$[52]$} \\
\hline 2 & $15-23 \mathrm{mths}$ & PLLA & $\begin{array}{c}\text { Screw } \\
\text {-struction }\end{array}$ & $\begin{array}{c}\text { ACL recon } \\
\text { screw fragment }\end{array}$ & Intra-articular & {$[53]$} \\
\hline 31 & $40-115 \mathrm{mths}$ & PLLA & Screws and rods & $\begin{array}{l}\text { Ankle } \\
\text { reaction }\end{array}$ & Foreign-body & {$[54]$} \\
\hline 19 & $8 \mathrm{mths}$ & PLLA/PDLLA & Suture anchor & Stabilization & Arthropathy & {$[55]$} \\
\hline 100 & n.d.* & PDLLA & Screw & Rotator cuff repair & Osteolysis & {$[56]$} \\
\hline 100 & n.d.* & PDLLA & Suture anchor & Rotator cuff repair & Disintegration & [57] \\
\hline 4 & $8 \mathrm{mths}$ & PDLLA (Sysorb) & - & ACL reconstruction & Pretibial cyst & {$[58]$} \\
\hline
\end{tabular}

Several excellent review articles have been published regarding the general topic of bioresorbable implants for internal fixation [6, 18, 59-61]. Instead of replicate these efforts, the goal of the present paper is to present a simple background into the available bioresorbable implants and to identify new developments and tendencies. 


\section{VARIETY OF BIORESORBABLE MATERIALS}

\subsection{Ceramics: Calcium Phosphates}

Calcium phosphates (CaPs) are found widely in the earth crust and are characterized as white solids unless doped or containing elements that pass in the lattice structure of the respective compound. CaPs are chemical compounds similar to the inorganic part of major normal (bones, teeth and antlers) and pathological calcified tissues of mammals [62-64]. CaPs can be categorized into bioactive and bioresorbable materials [65-66]. A bioactive biomaterial enables establishing direct chemical bonds with bone and surrounding tissues, and could provide good stabilization for materials that are subject to mechanical loading. $\beta$-tricalcium phosphate $(\beta$-TCP) and hydroxyapatite $(\mathrm{HA})$ are the most commonly used $\mathrm{CaPs}$ as ceramics. $\beta$-TCP is biodegradable and able to promote osteogenesis and new bone formation. HA is highly crystalline and is the most stable and least soluble $\mathrm{CaP}$ in an aqueous solution down to a $\mathrm{pH}$ of 4.2 [65]. The resorption of a ceramic HA is believed to be slow (1 to $2 \%$ per year), and once implanted into the body, HA may remain integrated into the regenerated bone tissue, while $\beta$-TCP is completely reabsorbed [67-68].

Unfortunately, CaPs have poor mechanical properties that do not allow load-bearing applications. However, advantages are achieved by combining these materials with polymers that are generally bioinert to provide the composite bioactivity, in order to form a composite with optimized properties. The composite implants are able to form a chemical bond with the host tissue, and the fixation of implants is accelerated [69-71]. For example, CaP/poly-DL-lactide-co-glycolide composite biomaterials exhibit good adhesion onto human cells, indicating a high level of biocompatibility [70-71]. Additionally, previous studies with composite materials consisting of PLLA/TCP or PLLA/HA showed a rapid resorption and replacement by newly formed bone tissue [72-74].

The elastic modulus of the composite can also be adjusted to approach that of the human bone by altering the content of ceramic. It is known that the match of elastic modulus between implants and the human bone favours the evasion of stress-shielding and the sequent bone absorption, which is often caused by implants with high elastic modulus [75].

\subsection{Polymers}

Bioresorbable fixation materials commonly used in orthopaedic applications are PGA, PLA, poly lactide-co-glycolide (PLGA) co-polymers in various ratios, polydioxanone (PDS), propylene (PP), polysulphone (PS), and polycarbonate (PC). Among them, PGA, PLA and their co-polymers have received the most attention, in part because they can be self-reinforced to achieve better strength properties [76]. The mechanical properties of these materials changes over time in a physiologic environment as determined by the molecular weight and degree of crystallinity. Hence, the molecular weight and crystallinity can be altered to optimize mechanical strength of an implant. For example, polymers with a higher degree of crystallinity are stronger and degrade slower than amorphous polymers with the same chemical composition [77]. 


\subsubsection{Polyglycolide - PGA}

PGA was the first bioresorbable polymer for reinforcing pins, screws and plates for bone surgery suggested by Schmitt and Polistina in 1969 [78]. PGA is a hard and crystalline polymer with an average molecular weight of 20000 to 145000 , a melting point of $224-230^{\circ} \mathrm{C}$, and a glass transition temperature of $36^{\circ} \mathrm{C}$ [79]. It is degraded in hydrolysis, and is broken down by nonspecific esterases and carboxy peptidases. Its mechanical strength is lost in 6 weeks, and it is totally resorbed in a few months depending on the molecular weight, purity, and crystallinity in addition to the size and shape of the implant [80-81]. However, adverse tissue responses to fixation implants made of PGA have been reported [82-85], with the incidence rate varying from 2.0 to $46.7 \%$ [60]. The highest incidence has been observed in fractures of the distal radius and the scaphoid bone [86-88]. Another work reported adverse tissue reaction in 5.3\% (107 reactions) of operations using self-reinforced-PGA implants [89]. Nevertheless, the frequency of foreign-body reactions significantly decreased when the dye was omitted from the PGA implant material [89-90]. The risk of adverse tissue reactions has deterred the use of PGA implants in favour of PLA, for example, which have lower rate of degradation.

PGA has been used mostly in sutures, rods and screws in fracture fixation of cancellous bone due to the rapid loss of mechanical strength of the implants [32, 34, 91].

\subsubsection{Polylactide - PLA}

PLA is a semicrystalline polymer with molecular weights of 180000 to 530000 , a melting point of about $174^{\circ} \mathrm{C}$, and glass transition temperature of $57^{\circ} \mathrm{C}$ [92]. Depending on the $\mathrm{L}$ and $\mathrm{D}$ configuration, it can exist in several distinct forms, such as PLLA and poly-D-lactide (PDLA) [93], and it is also degraded via hydrolysis. P(L/D)LA: PLLA is hydrophobic and crystallic and thus resistant to hydrolysis and degradation. By adding D-isomers into an L-isomer based polymerization system, polymer chains widen and cannot be packed as tightly as PLLA polymer chains. This results in a less crystallic and more rapidly degraded material [94].

PLLA interference screws and plates have been used successfully to fixate and heal tissue and bone, for injuries such as ligament damage and skeletal fractures. In the area of high-strength fracture fixation, PLLA is favoured by product specialists because of its slow rate of complete resorption into the body, although it does not have sufficiently high strength characteristics for use in the fixation of larger fractures such as those in the humerus and femur. Much of the referenced PLLA research has focused on veterinary applications using rabbits [95-96]. PDLLA (poly-DL-lactide) also shows characteristics that could be employed in high-strength situations, but PLLA is the preferred material for use in fracture fixation implants due to its higher strength compared with PDLLA [97].

In experimental studies, the biocompatibility of PLA has been well tolerated by the host tissue [98-101]. PDLLA and PLLA were well-tolerated and the tissue response inside muscle was similar to that of stainless steel [102]. A good biocompatibility has also been observed with PDLLA implants in craniomaxillofacial surgery [103]. PDLLA 
pins were compared with PDLLA (70:30) with $\beta$-TCP (10\%) and no different reaction in synovial membrane, lymph nodes, or bone formation was observed with either polymer [104]. Complete degradation of both materials occurred within 36 months. The implant channel was filled with cancellous bone or scar tissue.

However, some problems related to foreign-body reactions were reported although they should not be generalized to all PLLA materials. Eitenmüller et al. [105] used PLLA plates for fixation of ankle fractures, and observed that $52 \%$ of the patients demonstrated an aseptic soft tissue problem caused by delayed clearance of the degrading PLA particles. In a second protocol, smaller plates and screws did not cause any soft tissue reactions. Bergsma et al. [47] reported a late tissue response to PLLA bone plates and screws used in the fixation of ten zygomatic fractures in humans. Intraosseally implanted self-reinforced-PLLA screws and pins have been shown to cause similar, mild foreign-body reactions as corresponding metallic devices, without signs of inflammatory reactions during follow-up of 48 weeks $[98,106]$.

The total resorption time of PLA is considerably longer than PGA [102]. PGA screws have been shown to completely disappear within 6 months while PLLA has a very long degradation time and has been shown to persist in tissues for as long as five years post implantation [60]. Therefore, many resorbable orthopaedic implants are currently manufactured from PLLA. Toxicity is then minimized and biocompatibility is exceptional $[13,107]$. The incidence of adverse tissue reaction with PLA-based implants is lower from 0 to $1 \%$ [89].

PGA also differs from PLA in that PGA is a stronger acid and behaves more hydrophilically than PLA which is more hydrophobic because of its methyl groups. The decrease of $\mathrm{pH}$ values in the tissues adjacent to degrading biodegradable polymers may contribute to adverse effects, an issue that could be addressed by the incorporation of basic salts within the polymer [108].

\subsubsection{Co-polymers}

PGA and PLA can be combined to form a full range of PLGA polymers. Both L- and DL-lactides have been used for co-polymerization. Properties can be controlled by varying the ratio of glycolide to lactide for different compositions [109]. The rates of hydration and hydrolysis can be increased when the crystalline PGA is co-polymerized with PLA.

The degradation time of the co-polymer depends on the ratio of monomers used in synthesis. In general, the higher content of glycolide, the faster is the rate of degradation. For example, the degradation time is 5 months for a 85:15 PDLA:PGA co-polymer [110]. However, an exception to this rule is the 50:50 ratio of PGA:PLA, which exhibits the fastest degradation [111].

There are some concerns about the potential aseptic inflammatory wear debris generated during implant resorption. Caminear et al. [112] used 82:18 PLLA:PGA copolymer implants to fix distal chevron osteotomies in 15 patients and only one patient developed postoperatively a giant cell granuloma needing debridement. Andrews and 
Veznedaroglu evaluated the incidences of infection in a group of 296 patients in which 146 received craniotomy fixation with titanium implants and 150 received craniotomy fixation with a PDLLA co/polymer [113]. 43 patients in the titanium group and 37 patients in the polymer group also received postoperative irradiation. The incidence rate of infection was $4.6 \%$ for the titanium group and $4.0 \%$ for the resorbable polymer group.

Some resorbable membranes made of PLA:PGA have been used for guided bone regeneration (GBR) procedure [114-115]. These membranes generally start to resorb after 4 to 6 weeks. However, their stiffness and duration are questionable. Sandberg et al. [116] noted that some resorbable membranes used in their study demonstrated a lack of stiffness, resulting in collapse of the membrane into the defect area, causing the newly formed bone to take on an hourglass shape.

\section{CLINICAL EMPLOYMENTS OF BIORESORBABLE IMPLANTS}

The main applications of bioresorbable implants are to stabilize fractures, osteotomies, bone grafts and fusions mostly in trabecular bones, as well as to reattach ligaments, tendons, meniscal tears and other soft tissue structures [117-118]. The midfacial skeleton would seem to be an acceptable location for the use of bioresorbable implants, given the relatively easy access to fractures of this region and the low biomechanical stresses to which they would be exposed to. Andrews and Veznedaroglu studied the incidence of infection in patients after receiving craniotomy fixation with titanium and resorbable PDLA implants [113].

Bioresorbable fixation implants have also been used for the fixation of facial bones in orthognathic surgery, offering clinical advantages over titanium plates by eliminating the possible need for a second operation for their removal [119]. Fedorowicz et al. [119] evaluated the effectiveness of bioresorbable implants used in orthognathic surgery. Adverse effects were observed in two plate exposures between the third and ninth months, and occurred mainly in the posterior maxillary region. Known causes of infection were associated with loosened screws and wound dehiscence [119].

Bioresorbable implants have been also employed for management of foot and ankle fractures [7, 30-31, 34, 105, 120]. Eitenmuller et al. [105] investigated the suitability of PLLA screws and plates for the treatment of ankle fractures. Fractures healed within 6 weeks, but $52 \%$ of the patients experienced an aseptic soft tissue problem caused by delayed clearance of the degrading PLA particles. Prompted by these problems, the authors treated 7 patients with volume reduced plates and screws with flat heads, and none of the patients experienced any soft tissue reactions. The authors concluded that the use of PLLA screws and plates is acceptable for the fixation of ankle fractures, and soft tissue inflammatory reactions can be avoided by using implants with reduced volume of biodegradable material.

Bioresorbable implants have also been used in treating knee [121], wrist [122] and hand [1] injuries. Soft tissue reconstruction in complex knee injuries were performed by using meniscal tacks and biodegradable suture anchors [121]. Bioresorbable implants were successfully applied in the repair and reconstruction of many intra- 
articular and extra-articular abnormalities in the shoulder, such as shoulder instability, rotator cuff tears, and biceps lesions or biceps tendon tenodesis [123].

Applications of bioresorbable implants in spinal reconstructive surgery have been reported [59, 124-127]. For example, PLA screws were used for anterior cervical decompression and fusion procedures [125, 128]. Deguchi et al. [126] evaluated the biomechanical stability of PLLA pins in the posterior lumbar spine in comparison with other spinal implants, and showed that the PLLA pin construct provided improved stability to the spine, although it was not as stiff as the screw construct due to the sliding motion of the pins during testing.

Bioresorbable materials are also used in paediatric orthopaedics [45, 129-133]. Svensson et al. [45] reported the use of biodegradable osteosynthetic materials in 50 children with transphyseal or osteochondral fractures. Two patients had non-union of articular radial head fractures, possibly related to a foreign-body reaction. Illi et al. [132] evaluated the efficiency of PLLA implants in 32 children, aged 11 months to 17 years, with 15 cases of craniofacial malformations, 16 cases of neurotraumatological lesions and 1 case of refixation of an osteochondral flake of the patella. The follow-up time ranged from 3 months to 5.6 years, with an average of 3 years. The stability achieved was comparable to that of metal implants. No foreign-body reaction or local infections were observed, and it was not necessary to remove any of the resorbable implants. Furthermore, there was no interference with skull growth. In a study by Eppley et al. [133], where resorbable PLLA-PGA (LactoSorb) plate and screw fixation for craniofacial surgery was applied in 1883 infants and young children, it was observed that device-related complications requiring reoperation occurred in less than $0.5 \%$ of the implanted patients, which is less frequent than that reported for metallic bone fixation. Significant infectious complications occurred in $0.2 \%$, device instability primarily resulting from postoperative trauma occurred in $0.3 \%$, and self-limiting local foreign-body reactions occurred in $0.7 \%$ of the treated patients. The overall reoperation rate attributable to identifiable device-related problems was $0.3 \%$.

Bioresorbable membranes are used in several oral surgical procedures, such as sinus lifts [134-135] and GBR for the treatment of periodontal intraosseous defects [136-137].

\section{CONCLUSIONS}

Bioresorbable fracture implants are effective fixation devices offering significant advantages over the traditional metal implants. They retain their strength long enough to support healing of bone, and then gradually and harmlessly disintegrate in the patient's body. These implants can also be engineered to alter their material properties and degradation characteristics. Future developments of these materials as orthopaedic implants should be focused on the reduction of the foreign-body reaction and enhancement of the mechanical strength.

\section{CONFLICT OF INTEREST}

The authors indicated no potential conflicts of interest. 


\section{ACKNOWLEDGEMENTS}

Thanks are due to Centro de Investigação de Materiais Cerâmicos e Compósitos for the support and to the Portuguese Foundation for Science and Technology for the fellowship grant of Sandra Pina (SFRH/BPD/64119/2009).

\section{REFERENCES}

[1] Hughes TB. Bioabsorbable implants in the treatment of hand fractures: an update. Clinical Orthopedics. 2006, 445:169-174.

[2] Waris E, Konttinen YT, Ashammakhi N. Bioabsorbable fixation devices in trauma and bone surgery: current clinical standing. Expert Rev Med Devices. 2004, 1:229-240.

[3] Viljanen J, Kinnunen J, Bondestam S, Majola A, Rokkanen P, Tormala P. Bone changes after experimental osteotomies fixed with absorbable self-reinforced poly-L-lactide screws or metallic screws studied by plain radiographs, quantitative computed tomography and magnetic resonance imaging. Biomaterials. 1995, 16:1353-1358.

[4] Gristina AG. Biomaterial centered infection: microbial adhesion vs tissue integration. Science.1987, 237:1588-1595.

[5] Litsky AS. Clinical reviews: bioabsorbable implants for orthopaedic fracture fixation. Journal of Applied Biomaterials. 1993, 4:109-111.

[6] Pietrzak WS. Principles of development and use of absorbable internal fixation. Tissue Engineering. 2000, 6:425-433.

[7] Kukk A, Nurmi JT. A retrospective follow-up of ankle fracture patients treated with a biodegradable plate and screws. Foot and Ankle Surgery. 2009, 15:192-197.

[8] Stockmann P, Bohm H, Driemel O, Muhling J, Pistner H. Resorbable versus titanium osteosynthesis devices in bilateral sagittal split ramus osteotomy of the mandible - the results of a two centre randomised clinical study with an eight-year follow-up. Journal of Cranio-Maxillo-Facial Surgery. 2010, doi: 10.1016/j-jcms.2010.01.002.

[9] Mittal R, Morley J, Dinopoulos H, Drakoulakis EG, Vermani E, Giannoudis PV. Use of bio-resorbable implants for stabilisation of distal radius fractures: the United Kingdom patients' perspective. InjuryInternational Journal of the Care of the Injured. 2005, 36(2):333-338.

[10] Agins HJ, Alcock NW, Bansal M, Salvati EA, Wilson PD, Pellicci PM. Metallic wear in failed titanium alloy total hip replacements: A histological and quantative analysis. Journal of Bone and Joint Surgery American. 1988, 70:347-56.

[11] Kim YK, Yeo HH, Lim SC. Tissue response to titanium plates: A transmitted electron microscopic study. Journal of Oral Maxillofacial Surgery. 1997, 55:322-6.

[12] Alpert B, Seligson D. Removal of asymptomatic bone plates used for orthognathic surgery and facial fractures. Journal of Oral Maxillofacial Surgery. 1996, 54:618-21.

[13] Pistner H, Bend DR, Mühling J, Reuther J. Poly (1-lactide): a long-term degradation study in vivo: Part III. Analytical characterization Biomaterials. 1993, 14:291-298

[14] De Jong WH, Bersgma JE, Robinson JE, Bos RR. Tissue response to partially in vitro predegraded poly(L-lactide) implants. Biomaterials. 2005, 26:1781-1791.

[15] Gross KA, Berndt CC. Phosphates: geochemical, geobiological and materials importance. In: Mineralogical Society of America, Washington DC, 2002, 631-672.

[16] Cao W, Hench LL. Bioactive materials. Ceramics International. 1996, 22:493-507.

[17] Neo M, Kotani S, Fujita Y, et al. Differences in ceramic-bone interface between surface-active ceramics and resorbable ceramics: A study by scanning and transmission electron microscope. Journal of Biomedical Materials Research. 1992, 26:255-267.

[18] Dhillon MS, Lokesh AV. Bioabsorbable implants in orthopaedics. Indian Journal Orthopaedics. 2009, 40:205-209. 
[19] Vert M, Li MS, Spenlehauer G, Guerin P. Bioresorbability and biocompatibility of aliphatic polyesters. Journal of Materials Science. 1992, 3:432-446.

[20] Blasier RD, Bucholz R, Cole WG, Wohnson L, Makela E. Bioresorbable implants: applications in orthopaedic surgery. Instr Course Lec AAOS1997, 46:531-546.

[21] Yetkin H, Senkoylu A, Cila E, Özturk A, Simsek A. Biodegradable Implants in Orthopaedics and Traumatology. Turk Journal of Medical Science. 2000, 30:297-301.

[22] Peltoniemi H. Biocompatibility and fixation properties of absorbable miniplates and screws in growing calvarium: An experimental study in sheep. Helsinki, University Central Hospital, 2000.

[23] Kulkarni RK, Pani KC, Neuman C, Leonard F. Polyactic acid for surgical implants. Arch Surgery. 1966, 93:839-843.

[24] Kulkarni RK, Moore EG, Hegyeli AF, Leonard F. Biodegradable poly(lactic acid) polymers. Journal of Biomedical Materials Research. 1971, 5:169-181.

[25] Cutright DE, Hunsuck EE, Beasley JD. Fracture reduction using a biodegradable material, polylactic acid. Journal of Oral Surgery. 1971, 29:393-397.

[26] Raghoebar GM, Liem R, Bos R, Van Der Wal J, Vissink A. Resorbable screws for fixation of autologous bone grafts. Clinical Oral Impl Research. 2006, 17:288-293.

[27] Claes L. Requirements on resorbable implant materials. In: Clinical implant materials. Elsevier, Amsterdam, 1989.

[28] Claes L. Mechanical characterization of biodegradable implants. In: Biodegradable implants in orthopaedic surgery. Technik Kommunikation, Berlin, 1990, 83-93.

[29] Böstman S, Vainionpää E, Hirvensalo A. Biodegradable internal fixation for malleolar fractures. A prospective randomised trial. Journal of Bone Joint Surgery. 1987, 69:615-619.

[30] Bostman, Hirvensalo E, Vainionpaa S. Ankle fractures treated using biodegradable internal fixation. Clinical Orthopaedics. 1989, 238:195-203.

[31] Hirvensalo E. Fracture fixation with biodegradable rods: fourty-one cases of severe ankle fractures. Acta Orthopaedica Scandinav. 1989, 60:601-606.

[32] Böstman O, Hirvensalo E, Mäkinen J, Rokkanen P. Foreign body reactions to fracture fixation implants of biodegradable synthetic polymers. Journal of Bone Joint Surgery. , 1990, 72B:592-596.

[33] Böstman O. Intense granulomatous inflammatory lesions associated with absorbable internal fixation devices made of polyglycolide in ankle fractures. Clinical Orthopaedics. 1992, 278:193-198.

[34] Rokkanen P, Böstman O, Vainionpää S, Vihtonen K, Törmälä P, Laiho J. Biodegradable implants in fracture fixation: early results of treatment of fractures of the ankle. Lancet. 1985, 1:1422-1424.

[35] Lind M. Tibial bone tunnel widening is reduced by polylactate/hydroxyapatite interference screws compared to metal screws after ACL reconstruction with hamstring grafts. Knee, 2009, doi:10.1016/j.knee.2009.04.003.

[36] Hunt J, Callaghan J. Polymer-hydroxyapatite composite versus polymer interference screws in anterior cruciate ligament reconstruction in a large animal model. Knee Surgery and Sports Traumatology Arthroscospy. 2008, 16:655-660.

[37] SulzerMedica, 1999, http://www.staehelin.ch/SMJ/full-text-1.html

[38] Barber F, Herbert M, Click J. The ultimate strength of suture anchors. Arthroscopy. 1995, 11.

[39] Andersen S, Gehrchen PM, Brems E. Chevron osteotomy with biodegradable fixation of hallux valgus. Acta Orthopaedica Scandinav.1990, 61: 45.

[40] Bostman. Osteolytic changes accompanying degradation of absorbable fracture fixation implants. Journal of Bone Joint Surgery.1991, 73:679-682.

[41] Pelto K, Hirvensalo A, Bostman O. Treatment of radial head fractures with absorbable polyglycolide pins: a study on the security of the fixation in 38 cases. Journal Orthopaedics Trauma. 1994, 8:94-98.

[42] Partio EK, Bostman O, Hirvensalo A. The indication for the fixation of fractures with totally absorbable SR-PGA screws. Acta Orthopaedica Scandinav. 1990, 61:43. 
[43] Hirvensalo A, Bostman O, Patio E, Tormala P, Rokkanen P. Self-reinforced polyglycolide rods in 768 fractures and osteotomies. Acta Orthopaedics Scandinav. 1990, 61:43.

[44] Rokkanen PU. Absorbable materials in orthopaedic surgery. Annuals Medica. 1991, 23:109-115.

[45] Svensson P, Janarv P, Hirsch G. Internal fixation with biodegradable rods in pediatric fractures: one year follow-up of 50 patients. Journal of Pediatrics Orthopaedics. 1994, 14:220-224.

[46] Bucholtz R, Henry S, Henley M. Fixation with bioabsorbable screws for the treatment of fractures of the ankle. Journal of Bone Joint Surgery. 1994, 76:319-324.

[47] Bergsma JE, de Bruijn WC, Rozema FR, Bos RR, Boering G. Late degradation tissue response to poly(L-lactide) bone plates and screws. Biomaterials. 1995, 16:25-31.

[48] Cordewener F, Bos RR, Rozema FR, Houtman W. Poly (l-lactide) implants for repair of human orbital floor defects. Journal Oral Maxillofacial Surgery. 1996, 54:9-13.

[49] Pihlajamaki H, Bostman O, Hirvensalo E, Tormala P, Rokkanen PU. Absorbable pins of selfreinforced poly-1-lactic acid for fixation of fractures and osteotomies. Journal of Bone Joint Surgery. 1992, 74:853-857.

[50] Vihtonen K, Juutilainen T, Patiala H, Rockkanen P, Pellinen M, Tormala P. Fixation of ruptured ulnar collateral ligament of the first metacarpophalangeal joint with totally absorbable mini tack. 4th World Biomater Congress. Berlin, Germany, 1992.

[51] Athwal GS, Shridharani SM, O'Driscoll SW. Osteolysis and arthropathy of the shoulder after use of bioabsorbable knotless suture anchors: a report of four cases. Journal of Bone Joint Surgery American. 2006, 88:1840-1845.

[52] Muller M, Kaab MJ, Villiger C, Holzach P. Osteolysis after open shoulder stabilization using a new bio-resorbable bone anchor: a prospective, non-randomized clinical trial. Injury. 2002, 33B:30-36.

[53] Shafer BL, Simonian PT. Broken poly-L-lactic acid interference screw after ligament reconstruction. Arthroscopy. 2002, 18:35.

[54] Voutilainen NH, Hess M, Toivonen TS, Krogerus LA, Partio EK, Patiala HV. A long-term clinical study on dislocated ankle fractures fixed with self-reinforced polylevolactide implants. Journal Long Term Eff Med Implants. 2002, 12:35-52.

[55] Freehill M, Harms D, Huber S, Atlihan D, Buss D. Poly-l-lactic acid tack synovitis after arthroscopic stabilization of the shoulder. American Journal Sports Medicine. 2003, 31:643-647.

[56] Gaenslen E, Satterlee C, Hinson G. Magnetic resonance imaging for evaluation of failed repairs of the rotator cuff. Journal of Bone Joint Surgery. 1996, 78:1391-1396.

[57] Kelly J. Disintegration of an absorbable rotator cuff anchor six weeks after implantation. Arthroscopy. 2005, 21:495-497.

[58] Martinek V, Friederich NF. Tibial and pretibial cyst formation after anterior cruciate ligament reconstruction with bioabsorbable interference screw fixation. Arthroscopy. 1999, 15:317-320.

[59] Vaccaro AR, Singh K, Haid R. The use of bioabsorbable implants in the spine. Spine Journal. 2003, 3:227-237.

[60] Bostman O, Pihlajamaki H. Clinical biocompatibility of biodegradable orthopaedic implants for internal fixation: a review. Biomaterials. 2000, 21:2615-2621.

[61] Pietrzak WS, Sarver D, Verstynen M. Bioresorbable implants - practical considerations. Bone. 1996, 19:109S-119S.

[62] Dorozhkin SV. Calcium orthophosphates. Journal of Materials Science. 2007, 42(4):1061-1095.

[63] Addadi L, Weiner S. Control and design principles in biological mineralization. Angew Chemistry. 1992, 104:159-176.

[64] Bauerlein E. Biomineralization: Wiley-VHC, Weinheim, 2000.

[65] Bohner M. Calcium orthophosphates in medicine: from ceramics to calcium phosphate cements. Injury-International Journal of the Care of the Injured. 2000, 31:37-47. 
[66] Bohner M. Resorbable biomaterials as bone graft substitutes. Materials Today. 2010, 13:24-30.

[67] Ginebra MP, Traykova T, Planell JA. Calcium phosphate cements as bone drug delivery systems: A review. Journal of Controlled Release. 2006, 113(2):102-110.

[68] Takahashi Y, Yamamoto M, Tabata Y. Osteogenic differentiation of mesenchymal stem cells in biodegradable sponges composed of gelatin and beta-tricalcium phosphate. Biomaterials. 2005, 26:35-87.

[69] Elgendy H, Norman M, Keaton A, Laurencin C. Osteoblast-like cell (MC3T3-E1) proliferation on bioerodible polymers: an approach towards the development of a bone-bioerodible polymer composite biomaterials. Biomaterials. 1993, 14:263-269.

[70] Ignjatovic N, Ninkov P, Kojic V. Cytotoxicity and fibroblast properties during in vitro test of biphasic calcium phosphate/poly-dl-lactide-co-glycolide biocomposites and different phosphate materials. Microscopy Research Technology. 2006, 69:976-982.

[71] Durucan C, Brown P. Calcium-deficient hydroxyapatite-PLGA composites: mechanical and microstructural investigation. Journal of Biomedical Materials Research. 2000, 51:726-734.

[72] Higashi S, Yamamuro T, Nakamura T, Ikada Y, Hyon S, Jamshidi K. Polymer-hydroxyapatite composites for biodegradable bone fillers. Biomaterials. 1986, 7:183-187.

[73] Fischer J, Ruffieux K, Jeschkeit S, Heidemann W, Gerlach K, Wintermantel E. In vivo versus in vitro evaluation of poly(D, L)lactide rods including calcium phosphate particles. In: International Symposium on Biodegradable Materials, Hamburg, 1996.

[74] Prokop A, Helling H, Fischbach R. Neue biodegradierbare Tricalciumphosphat- Polylactidstifte zur Refixation osteochondraler Fragmente. Erste radiologische Ergebnisse einer tierexperimentellen. 3rd European Trauma Congress, Amsterdam, 1998.

[75] Zhang G, Latour RAJ, Kennedy JM, Del Schutte HJ, Friedman RJ. Long-term compressive property durability of carbon fibre-reinforced polyetheretherketone composite in physiological saline. Biomaterials. 1996, 17:781-789.

[76] Gunja NJ, Athanasiou KA. Biodegradable materials in arthroscopy. Sports Medicine Arthroscopy. 2006, 14:112-119.

[77] Siparski PN, Gramen P, Gall K, Dambrosia R. Bioabsorbable polymers used in knee arthroscopy, part 1: basic science and application. Tech Knee Surgery. 2006, 5:193-198.

[78] Schmitt E, Polistina R. Polyglycolic acid prosthetic devices. 1969, US Patent 3463158.

[79] Frazza EJ, Schmitt E. A new absorbable suture. Journal of Biomedical Materials Research Symposium. 1971, 1:43-58.

[80] Vainionpää S, Rokkanen P, Törmälä P. Surgical applications of biodegradable polymers in human tissues. Prog Polym Science. 1989, 14:679-716.

[81] Gerlach KL, Eitenmüller J. In vivo evaluation of 8 different polymers for use as osteosynthesis material in maxillo-facial surgery: Biomaterials and Clinical Applications. Amsterdam: Elsevier Science Publisher B.V., 1987.

[82] Bostman O, Pihlajamaki HK. Adverse tissue reactions to bioabsorble fixation devices. Clinical Orthopaedics. 2000, 371:216-227.

[83] Hovis WD, Bucholz RW. Polyglycolide bioabsorbable screws in the treatment of ankle fractures. Foot Ankle International. 1997, 18:128-131.

[84] Frokjaer J, Nue Moller B. Biodegradable fixation of ankle fractures. Complications in a prospective study of 25 cases. Acta Orthopaedica Scandinav. 1992, 63:434-436.

[85] Bostman O, Makela EA, Sodergard J, Hirvensalo E, Tormala P, Rokkanen P. Absorbable polyglycolide pins in internal fixation of fractures in children. Journal of Pediatric Orthopaedics. 1993, 13:242-245.

[86] Casteleyn PP, Handelberg F, Haentjens P. Biodegradable rods versus Kirschner wire fixation of wrist fractures. A randomised trial. Journal of Bone and Joint Surgery. 1992, 74:858-861. 
[87] Hoffmann R, Krettek C, Hetkamper A, Haas N, Tscherne H. Osteosynthesis of distal radius fractures with biodegradable fracture rods. Results of two years follow-up. Der Unfallchirurg. 1992, 95:99-105.

[88] Pelto-Vasenius K, Hirvensalo E, Böstman OM, Rokkanen PU. Fixation of scaphoid delayed union and non-union with absorbable polyglycolide pin or Herbert screw. Consolidation and functional results. Archives of Orthopaedic and Trauma Surgery. 1995, 114:347-351.

[89] Böstman OM, Pihlajamäki HK. Adverse tissue reactions to bioabsorbable fixation devices. Clinical orthopaedics and Related Research. 2000, 371:216-227.

[90] Partio EK. Absorbable screws in the fixation of cancellous bone fractures and arthrodeses. Helsinki University Central Hospital, 1992.

[91] Partio EK, Böstman O, Hirvensalo E, Vainionpää S, Vihtonen K, Pätiälä H. Self-reinforced absorbable screws in fixation of displaced ankle fractures: A prospective clinical study of 152 patients. Journal of Orthopaedics Trauma. 1992, 6:209-215.

[92] Vert M, Christel P, Chabot F, Leray J. Macromolecular Biomaterials: Bioresorbable plastic materials for bone surgery. Boca Raton, FL, CRC Press, 1984.

[93] Holten C. Lactic acid. Verlag Chemie, Weinheim, 1971.

[94] Ashammakhi N, Peltoniemi H, Waris E. Developments in craniomaxillofacial surgery: Use of selfreinforced bioabsorbable osteofixation devices. Plast Reconstr Surgery. 2001, 108:167-180.

[95] Shikinami Y, Matsusueb Y, Nakamura T. The complete process of bioresorption and bone replacement using devices made of forged composites of raw hydroxyapatite particles/poly L-lactide (F-u-HA/PLLA). Biomaterials. 2005, 26:5542-5551.

[96] Hochuli-Vieira E, Cabrini GM, Pereira-Filho VA, Gabrielli MF, Padilha JG. Rigid Internal Fixation with Titanium versus Bioresorbable Miniplates in the Repair of Mandibular Fractures in Rabbits. International Journal Oral Maxillofacial Surgery. 2005, 34:167-173.

[97] Farrar D. Business Briefing: Medical Device Manufacturing and Technology, 2005.

[98] Majola A, Vainionpää S, Vihtonen K. Absorption, biocompatibility, and fixation properties of polylactic acid in bone tissue: an experimental study in rats. Clinical Orthopaedics and Related Research. 1991, 260-9.

[99] Cutright DE, Hunsuck EE. The repair of fractures of the orbital floor using biodegradable polylactic acid. Oral Surgery and Oral Medicine. 1972, 33:28-34.

[100] Matsusue Y, Hanafusa S, Yamamuro T, Shikinami Y, Ikada Y. Tissue reaction of bioabsorbable ultra high strength poly (L-lactide) rod. A long-term study in rabbits. Clinical Orthopaedcis and Related Research. 1995, 246-53.

[101] Nordström P, Pihlajamäki H, Toivonen T, Törmälä P, Rokkanen P. Tissue response to polyglycolide and polylactide pins in cancellous bone. Arch Orthopaedic Trauma Surgery. 1998, 117: 197-204.

[102] Kulkarni RK, Moore EG, Hegyeli AF, Leonard F. Biodegradable poly(lactic acid) polymers. Journal of Biomedical Materials Research. 1971, 5B:169-181.

[103] Ashammakhi N, Peltoniemi H, Waris E. Developments in craniomaxillofacial surgery: use of selfreinforced bioabsorbable osteofixation devices. Plastic Reconstruction Surgery. 2001, 108:167-80.

[104] Prokop A, Jubel A, Helling HJ. Soft tissue reactions of different biodegradable polylactide implants. Biomaterials. 2004, 5:259-267.

[105] Eitenmuller J, David A, Pommer A, Muhr G. Surgical treatment of ankle joint fractures with biodegradable screws and plates of poly-L-lactide. Chirurgery.1996, 67:413-418.

[106] Viljanen J, Pihlajamaki H, Tormala P, Rokkanen P. Comparison of the tissue response to absorbable self-reinforced polylactide screws and metallic screws in the fixation of cancellous bone osteotomies: an experimental study on the rabbit distal femur. Journal of Orthopaedics Research. 1997, 15:398-407.

[107] Cutright DE, Hunsuck EE. Tissue reaction to the biodegradable PLA suture. Oral Surgery. 1971, 31:134. 
[108] Agrawal CM, Athanasiou KA. Technique to control pH in vicinity of biodegrading PLA-PGA implants. Journal of Biomedical Materials Research. 1997, 38:105-114.

[109] Cohn D, Younes H, Marom G. Amorphous and crystalline morphologies in glycolic acid and lactic acid polymers. Polymer. 1987, 28:2018.

[110] Lewis DH. Controlled release of bioactive agents from lactide/glycolide polymers. In: R CML (ed). Biodegradable Polymers as Drug Delivery Systems, Marcel Dekker, New York, 1990, 1-43.

[111] Park TG, Lu W, Crotts G. Importance of in vitro experimental conditions on protein release kinetics, stability and polymer degradation in protein encapsulated poly (D, L-lactic acid-co-glycolic acid) microspheres. Journal Control Release. 1995, 33:211-222.

[112] Caminear DS, Pavlovich R, Jr, Pietrzak WS. Fixation of the chevron osteotomy with an absorbable copolymer pin for treatment of hallux valgus deformity. Journal of Foot Ankle Surgery. 2005, 44:203-210.

[113] Andrews DW, Veznedaroglu E. Neurosurgical applications of resorbable fixation. In: Symposium on craniofacial distraction with biodegradable devices, Columbia University College of Physicians \& Surgeons, New York, 2000.

[114] Simion M, Scarano A, Gionso L, Picttelli A. Guided bone regeneration using resorbable and nonresorbable membranes: A comparative histological study in humans. International Journal Oral Maxillofacial Implant. 1996, 11:735-42.

[115] Rosen P, Reynolds M. Guided bone regeneration for dehiscence and fenestration defects on implants using an absorbable polymer barrier. Journal Periodontology. 2001, 72:250-6.

[116] Sandberg E, Dahlin C, Linde A. Bone regeneration by the osteopromotion technique using bioabsorbable membranes: An experimental study in rats. Journal Oral Maxillofacial Surgery. 1993, 51:1106-14.

[117] Bostman O. Current concepts review: absorbable implants for the fixation of fractures. Journal of Bone Joint Surgery American. 1991, 73:148-153.

[118] Tunc DC, Rohovsky MW, Zadwadsky JP, Spieker JE, Strauss ED. Evaluation of body absorbable screw in avulsion type fractures. Annual Meeting of the Society for Biomaterials, 1986.

[119] Fedorowicz Z, Nasser M, Newton T, Oliver R. Resorbable versus titanium plates for orthognathic surgery. Cochrane Database of Systematic Reviews 2007 (2). Art. No.: CD006204. DOI: 10.1002/14651858.CD006204.pub2

[120] Frokjaer J, Nue Moller B. Biodegradable fixation of displaced ankle fractures. Acta Orthopaedica Scandinav. 1989, 231:12.

[121] Burkhart SS. The evolution of clinical applications of biodegradable implants in arthroscopic surgery. Biomaterials. 2000, 21:2631-2634.

[122] van Manen CJ, Dekker ML, van Eerten PV, Rhemrev SJ, van Olden GD, van der Elst M. Bioresorbable versus metal implants in wrist fractures: a randomised trial. Arch Orthop Trauma Surgery. 2008, 128:1413-1417.

[123] McFarland EG, Park HB, Keyurapan E, Gill HS, Selhi HS. Suture anchors and tacks for shoulder surgery. Part 1: biology and biomechanics. American Journal Sports Medicin., 2005, 33: 1918-1923.

[124] Coe JD, Vaccaro AR. Instrumented transforaminal lumbar interbody fusion with bioresorbable polymer implants and iliac crest autograft. Spine. 2005, 1: 76-83.

[125] Brunon J, Duthel R, Fotso MJ, Tudor C. Anterior osteosynthesis of the cervical spine by phusiline bioresorbable screws and plates. Neuro-Chirurgie. 1994, 40:196-202.

[126] Deguchi M, Cheng B, Sato K, Matsuyama Y. Biomechanical evaluation of translaminar facet joint fixation. Spine. 1998, 23:1307-18.

[127] Johnsson R, Axelsson P, Stromqvist B. Posterolateral lumbar fusion using facet joint fixation with biodegradable rods: a pilot study. Spine Journal. 1997, 6:144-8.

[128] Subach BR, Haid RW, Rodts GE, Branch CE, Alexander JT. Posterior lumbar interbody fusion (PLIF) using an impacted, bioabsorbable device. American Association of Neurological Surgeons, Congress of Neurological Surgeons. Orlando, FL, 1999. 
[129] Bostman, Makela EA, Tormala P, Rokkanen P. Transphyseal fracture fixation using biodegradable pins. Journal Bone Joint Surgery. 1989, 71: 701-707.

[130] Hope PG, Williamson DM, Coates CJ, Cole WG. Biodegradable pin fixation of elbow fractures in children: a randomized trial. Journal Bone Joint Surgery. 1991, 73:965-968.

[131] Partio ES, Merikanto J, Heikkila JT. Totally absorbable screws in fixation of subtalar extraarticular arthrodesis in children with spastic neuromuscular disease: preliminary report of a randomized prospective study of 14 arthrodeses fixed with absorbable metallic screws. Journal Paediatric Orthopaedics. 1992, 12:646-650.

[132] Illi OE, Gitzelmann C, Gasser B, Misteli F, Ruedi M. Five years of experience with biodegradable implants in paediatric surgery. Journal of Materials Science: Materials in Medicine. 1994, 5:417-423.

[133] Eppley BL, Morales L, Wood R. Resorbable PLLA-PGA Plate and Screw Fixation in Pediatric Craniofacial Surgery: Clinical Experience in 1883 Patients. Plastic Reconst Surgery. 2004, 114:850-856.

[134] Pjetursson BE, Tan WC, Zwahlen M, Lang NP. A systematic review of the success of sinus floor elevation and survival of implants inserted in combination with sinus floor elevation. Part I - Lateral technique. Journal Clinical Periodontology. 2008, 35:216-240

[135] Listl S, Faggion CMJ. An economic evaluation of different sinus lift techniques. Journal Clinical Periodontology. 2010, 37:777-787.

[136] Zybutz M, Laurell L, Rapoport D, Persson G. Treatment of intrabony defects with resorbable materials, non-resorbable materials and flap debridement. Journal Clinical Periodontology. 2000, 27:169-178.

[137] Listl S, Tu Y-K, Faggion CJ. A cost-effectiveness evaluation of enamel matrix derivatives alone or in conjunction with regenerative devices in the treatment of periodontal intra-osseous defects. Journal Clinical Periodontology. 2010, 37:920-927. 


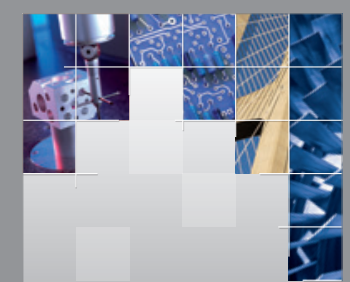

\section{Enfincering}
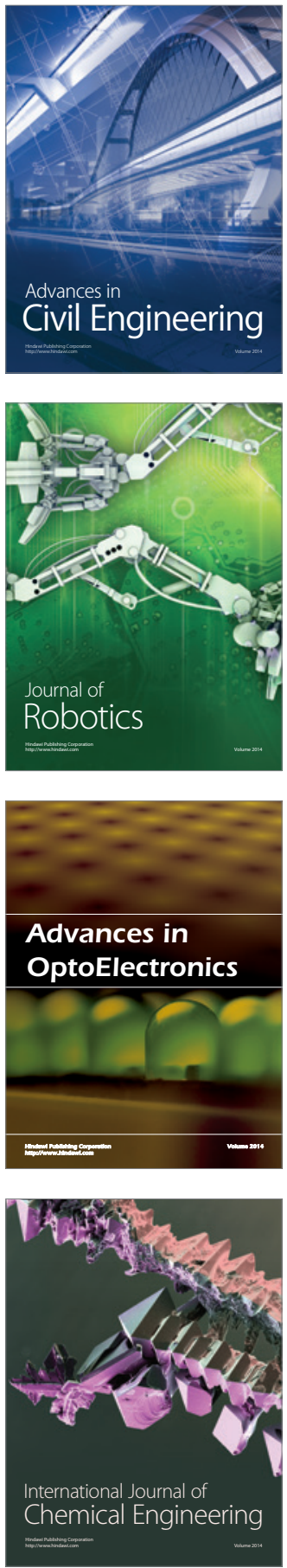

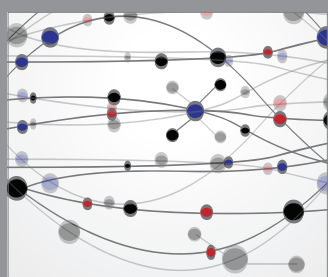

The Scientific World Journal

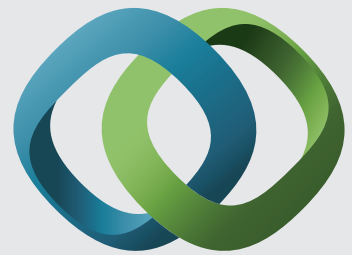

\section{Hindawi}

Submit your manuscripts at

http://www.hindawi.com
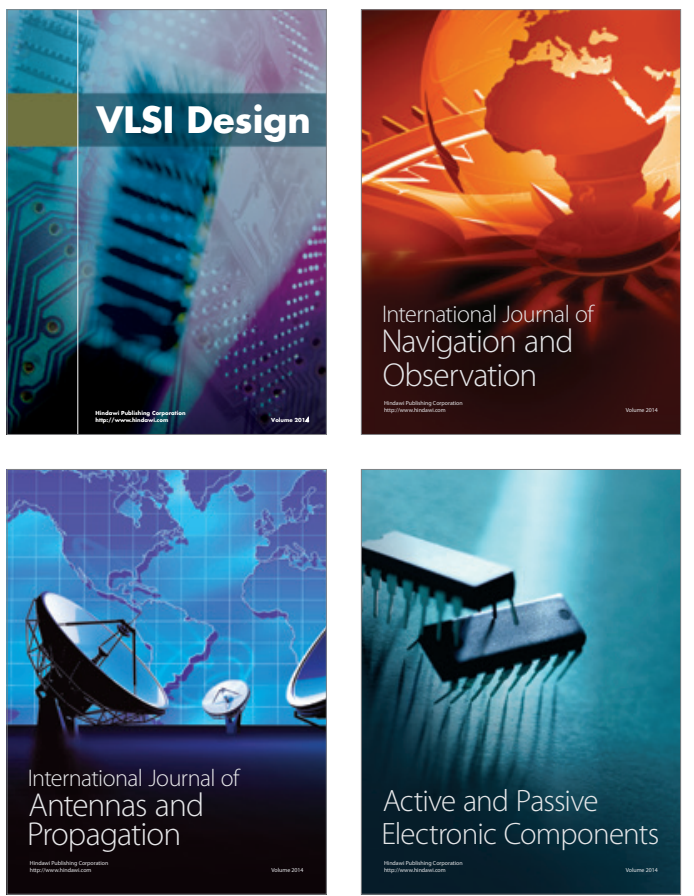
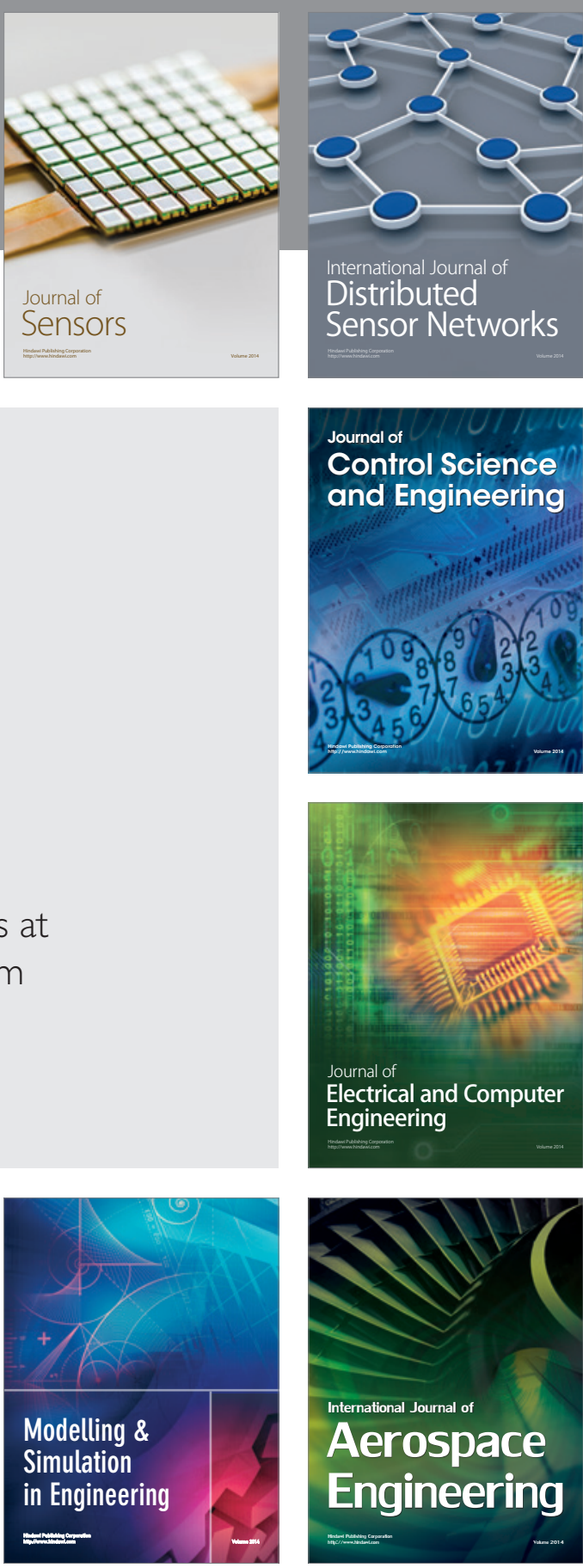

International Journal of

Distributed

Sensor Networks

Journal of

Control Science

and Engineering
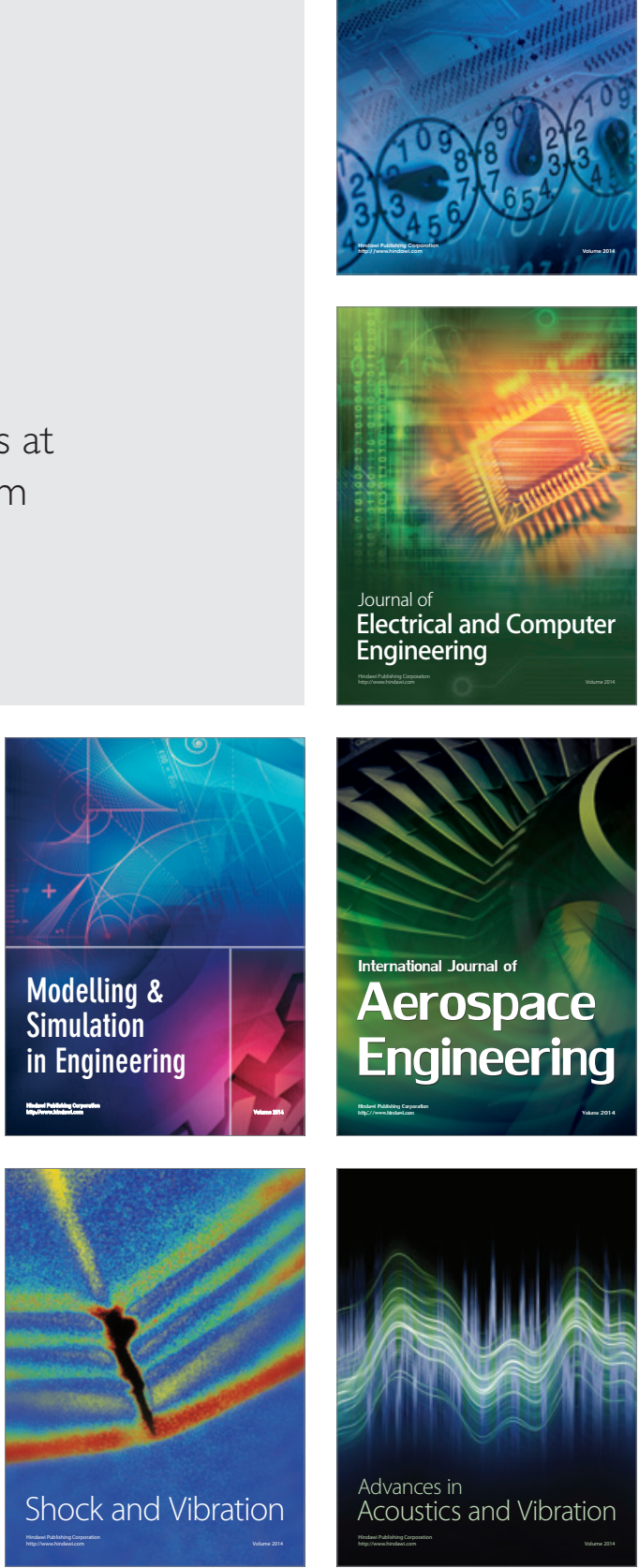